Available Online : https://proceeding.researchsynergypress.com/index.php/cset/index

RSF Conference Series: Engineering and Technology

ISSN 2809-6843 (Online) | 2809-6878 (Print)

Volume 1 Number 1 (2021): 580-589

\title{
Survey Analysis of Enhanced Oil Recovery (EOR) Laboratory towards Featured Research Laboratory
}

\author{
Harry Budiharjo Sulistyarso 1, Dyah Rini Ratnaningsih', Joko Pamungkas', Indah \\ Widiyaningsih, Salma Azizah ${ }^{1}$
}

1 Petroleum Engineering Department, UPN “Veteran” Yogyakarta, Indonesia

\begin{abstract}
The EOR Research Laboratory is a laboratory that was independently pioneered by the Department of Petroleum Engineering UPN "Veteran" Yogyakarta. The EOR Research Laboratory needs to be improved especially for the existing spatial layout to support the ongoing and future research. This Institutional Research will cover the planning process of spatial layout design, spatial layout realization, internal and external EOR Research Laboratory socialization, and at the end of the study, effective and efficient governance will be applied to adapt to the current pandemic conditions. The method used in this research is quantitative in the form of socialization, questionnaires, and survey analysis to find out how EOR Laboratory is well known among students. This research is expected to be able to introduce the EOR Research Laboratory in a wider range and carrying out sustainable research in the future so that it will support the planning of the laboratory to be the Leading EOR Research Laboratory at the Department of Petroleum Engineering, UPN "Veteran" Yogyakarta.
\end{abstract}

Keywords: Leading Research, EOR Laboratory, survey analysis

This is an open access article under the CC-BY-NC license

\section{INTRODUCTION}

The study is about Enhanced Oil Recovery (EOR) Laboratory towards featured research laboratory needs to be accomplished as the first step to evaluation overall of the EOR Research Laboratory. Thus, the improvement planning of the laboratory can be realized and the expectancy outcome of this study is a leading research laboratory predicate in UPN al "Veteran" Yogyakarta can be achieved.

The EOR Research Laboratory is a facility and a place to support the research activity, especially which is related in advanced oil recovery methods. The EOR Research Laboratory is a laboratory that was independently pioneered by the Department of Petroleum Engineering. This laboratory is located on Campus II Babarsari and is equipped with some tools that support research in their fields such as Viscosimeter, Tensiometer (to measure interfacial tension/IFT), Gas Chromatograph (GC), and tools to determine the amount of recovery in oil reservoirs, also Coreflooding apparatus.

In the current condition, the EOR Research Laboratory has a simple layout. In the early stages, a more effective and efficient spatial design has been carried out and can be applied to the EOR Research Laboratory. In the process of applying effective and efficient spatial planning, it is very necessary to realize the Excellence Research Laboratory at the UPN "Veteran"Yogyakarta.

This Institutional Research will provide training in the form of FGDs to promote the EOR Research Laboratory so that it is well recognized outside of the UPN "Veteran" Yogyakarta, especially for parties who can cooperate such as companies. The results of this study are expected to improve the current condition of the EOR Research Laboratory and of course to be even better in the field of research between lecturers and students in the Department of Petroleum Engineering for both undergraduate and postgraduate studies.

The aims and objectives of this institutional research are as follows:

1. To complete some inadequacies of the EOR Research Laboratory.

Corresponding author:

harry_hb@upnyk.ac.id

DOI: $10.3198 /$ cset.v1i1.433

Research Synergy Foundation 
2. Improving the existing spatial conditions so that it meets the standards of the University Research Laboratory.

3. Socializing the EOR Research Laboratory outside UPN "Veteran" Yogyakarta and to companies that are under the field of Petroleum Engineering.

4. More effective and efficient Laboratory management to support the realization of a Leading EOR Research Laboratory.

This Institutional Research is expected to specifically support the Department of Petroleum Engineering in achieving the vision and mission of the Department of realizing a University Excellence Research Laboratory.

\section{LITERATURE REVIEW}

This research will focus on the spatial management of the EOR Research Laboratory and effective and efficient laboratory management to support Higher Education Excellence Research in the UPN "Veteran" Yogyakarta environment. Management is to manage is to forecast and plan, to organize, to command, to co-ordinate and to control. To foresee and provide means examining the future and drawing up the plan of action. To organize means building up the dual structure, material and human, of the undertaking. To command means maintaining activity among the personnel. To coordinate means binding together, unifying and harmonizing all activity and effort. To control means seeing that everything occurs in conformity with established rule and expressed command (Fayol,1916).

Management Engineering Laboratory has evaluated the effectiveness of management which includes documentation of labs, lab environment, safety, and equipment. Ahmad Fauzi's study (2005), suggests Ministry of Higher Education should streamline the management of physical resources to avoid wastage and to formulate strategies to help guide the institution to achieve its visions and goals. According to Fauzi, they have a user property, and objects (physical resources) are great. The size of this resource inventory is to provide the cost, maintenance and operations, and technical complexities which are developing rapidly. The elements of quality management are to ensure that key aspects can be implemented efficiently. Accountability and skills possessed by the laboratory management are very helpful in shaping the quality of engineering labs.

\section{EOR Lab \\ Spatial \\ Layout \\ Creation}

Figure 1. Road Map of research that is already underway and planned 
The current condition of the EOR Research Laboratory as the basis for the formulation of the problem is:

1. Inadequate spatial layout of the assignation of laboratory equipment and materials, which includes oil and formation water samples from several oil and gas companies in Indonesia.

2. Lack of familiarity with EOR Research Laboratories both inside and outside the campus.

3. Laboratory management is less effective and efficient, especially during a pandemic, so it is necessary to adjust conditions.

Thus, the laboratory is necessary to be improved the spatial conditions to support research that will behold at the EOR Research Laboratory. Hold training or Focus Group Discussion (FGD) is required regarding the socialization of the EOR Research Laboratory in the internal and external campus environment.

\section{RESEARCH METHODOLOGY}

The research methodology uses a scientific way to obtain data with a specific purpose and use. Based on this, four keywords need to be considered, namely the scientific method, data, purpose, and usability. The population of this research is the students of the Department of Petroleum Engineering, UPN "Veteran" Yogyakarta. The research data was taken using a systematic sampling method by taking samples about knowledge of the EOR laboratory to petroleum engineering students at UPN "Veteran" Yogyakarta. The subjects studied were the EOR laboratory located on campus 2 of UPN "Veteran" Yogyakarta, a laboratory that is often used for EOR research but is not included in the mandatory practicum in petroleum engineering UPN "Veteran"Yogyakarta.

The research variables were the knowledge of the existence of an EOR laboratory in Petroleum Engineering, the location of the EOR laboratory, interest in EOR, and knowledge of the use of equipment in the EOR laboratory. Respondents were 22 students of petroleum engineering class 2018 who have studied for almost 4 years and have attended face-to-face learning and have participated in practicums in various laboratories in petroleum engineering. Data collection was carried out in the even semester of 2020/2021.

The data analysis technique was carried out from a systematic random sample obtained by making a percentage of each answer and analyse the understanding and knowledge of petroleum students at UPN Veterans Yogyakarta regarding the EOR Laboratory in the Department of Petroleum Engineering at UPN "Veteran" Yogyakarta.

This research will go through stages in an effective and efficient spatial planning process. At the initial stage, spatial arrangements hold according to the existing layout design. After the spatial planning hold according to the plan, then socialization regarding the EOR Research Laboratory has been carried out to internal departments and universities, and in the final stage, socialization went to external parties of the university. 


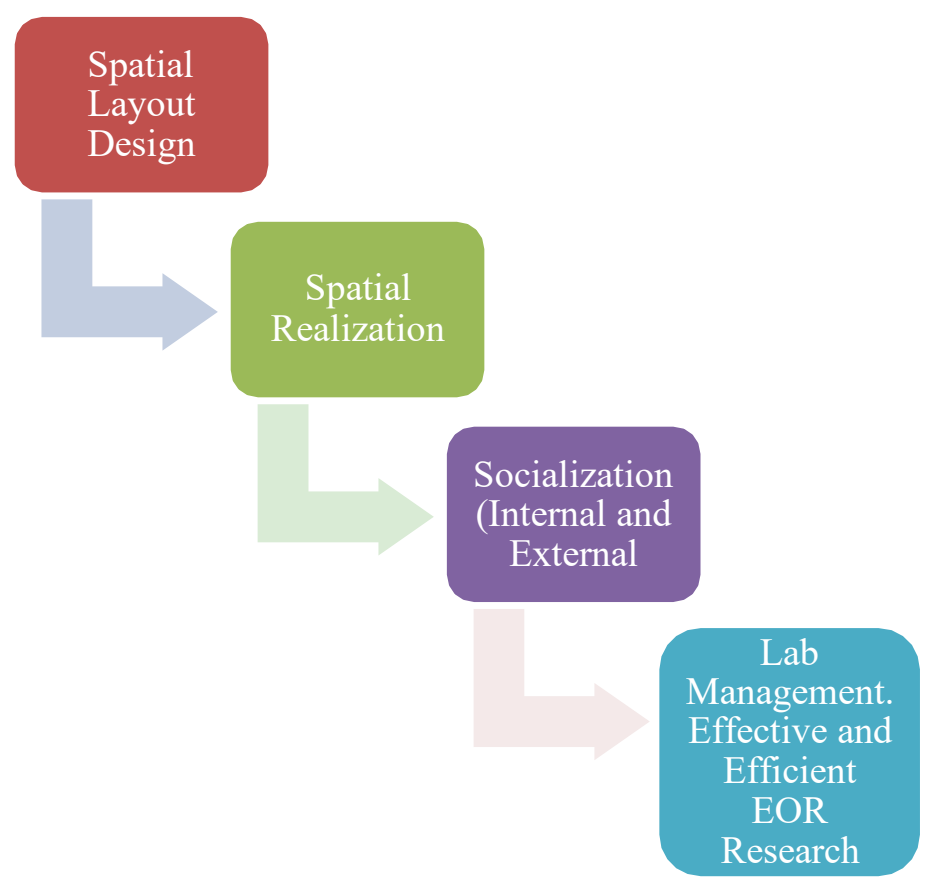

Figure 2. Research flow chart

\section{FINDING AND DISCUSSION}

The questionnaire has been deployed to 52s bachelor degree students of the Petroleum Engineering Department as respondents to determine their interest and knowledge about the EOR Research Laboratory. The target respondents have completed the questionnaire. The result provides valuable data shown in the presented charts below:

The first question is about the awareness of the students about the existence of an EOR Laboratory in the Department of Petroleum Engineering. The result informs us about how it is regarded as high rate awareness about the existence of an EOR Laboratory.

Are you aware of the existence of an EOR Laboratory in the Department of Petroleum Engineering?

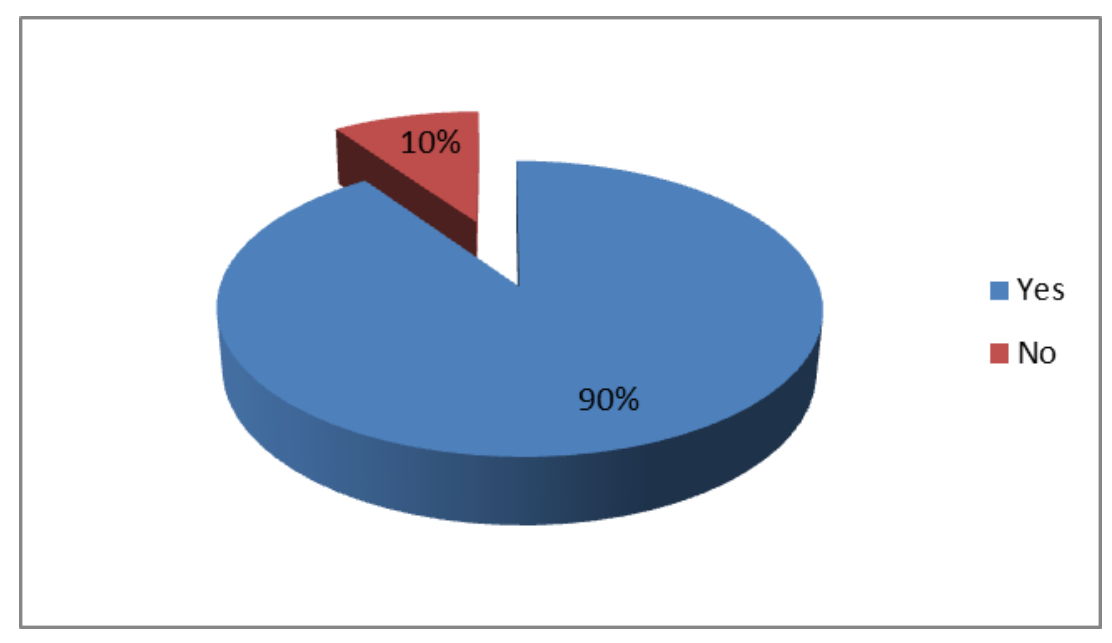

Figure 3. Student awareness of the existence of an EOR Laboratory

From the 52 respondents, 90\% (about 47 people out of 52) answered yes, and 10\% (about 5 people out of 52) answered no to the question of the existence of the EOR laboratory. So it can be concluded 
that most students who have taken almost 4 years of college are aware that there is an EOR laboratory in the petroleum department of UPN "Veteran" Yogyakarta.

Where is the location of the EOR Laboratory in the Department of Petroleum Engineering?

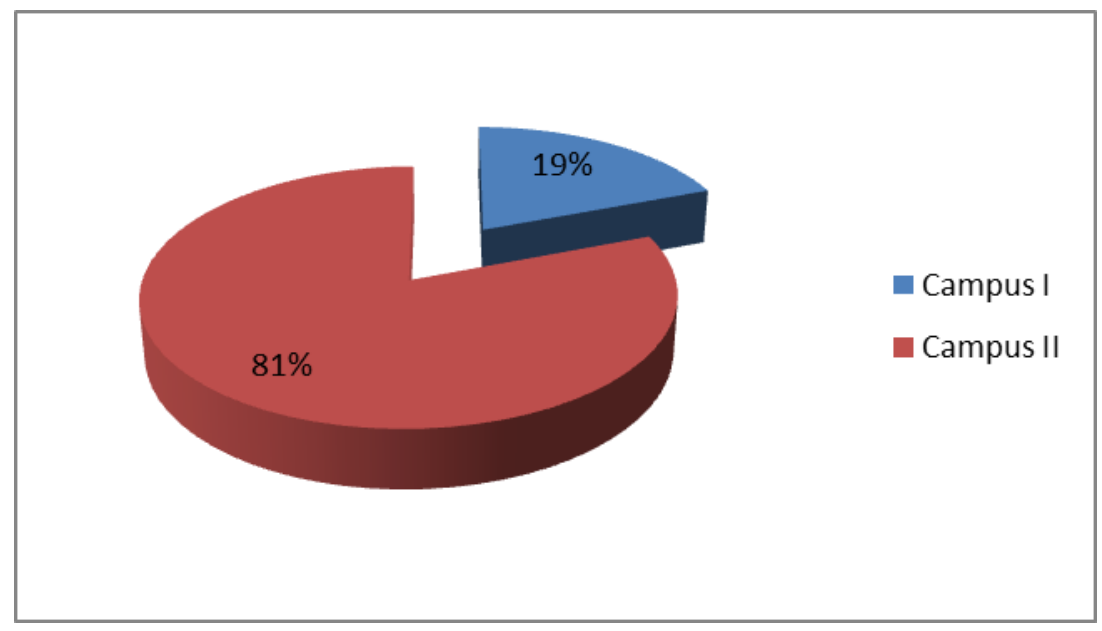

Figure 4. Student's knowledge about the location of the EOR Laboratory

The second question is about the knowledge of the students about the location of the EOR Laboratory in the Department of Petroleum Engineering. The result informs us about how it is regarded as low rate knowledge about the location of the EOR Laboratory.

However, when asked about the location of the EOR laboratory in the petroleum department, from 42 respondents, $81 \%$ (42 of 52) answered that the laboratory was located on the Campus I North Ring Road and 19\% (10 of 52) answered that it was on the Campus II Babarsari. The EOR laboratory is located on the campus II Babarsari UPN "Veteran" Yogyakarta, so most students do not know for sure the location of the EOR laboratory at UPN "Veteran" Yogyakarta. Whereas in the previous question $90 \%$ knew about the existence of a laboratory but it turned out that $81 \%$ of them did not know the location of the EOR laboratory. So far they only understand that it exists but do not know its exact location. This is a consideration to pay more attention to the introduction of the EOR laboratory more widely.

Are you interested in researching in the EOR Laboratory?

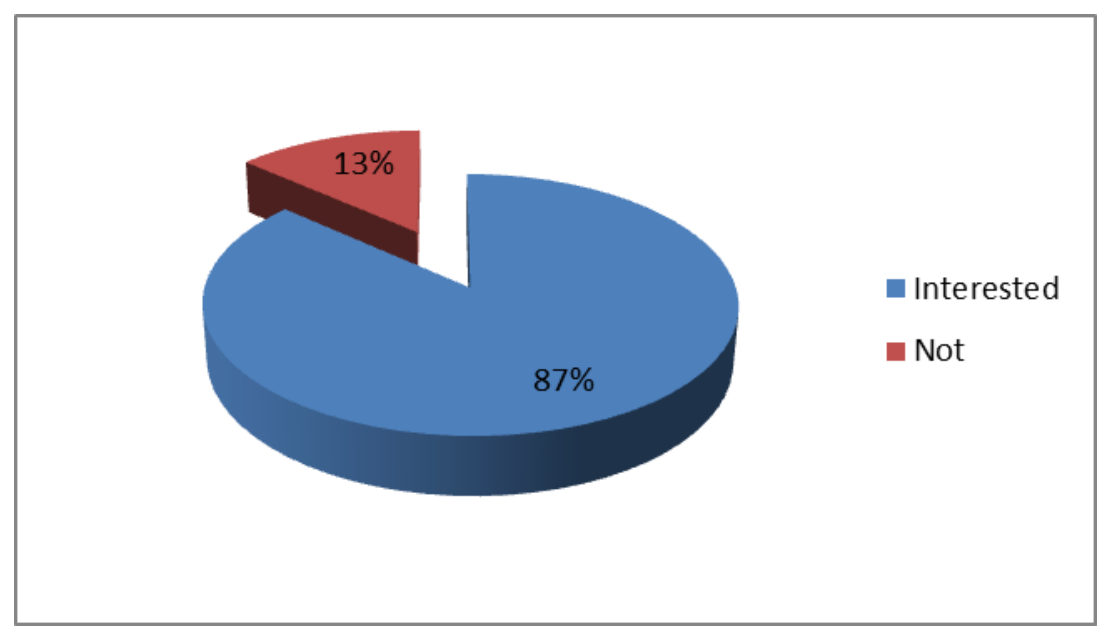

Figure 5. Student's interest in researching in the EOR Laboratory

In the third question, $87 \%$ of the 52 respondents (45 out of 52) are interested in doing research in the EOR Laboratory and 13\% (7 of 52) are not. Most of the respondents are interested in researching 
in the EOR Laboratory. This will hinder those who are interested in research because of the lack of information about the EOR laboratory at UPN "Veteran" Yogyakarta. With the enthusiasm of students towards research in the EOR laboratory, it is a loss if it is not used properly.

More knowledge of the EOR lab will increase the number of researches on EOR conducted by veteran UPN Yogyakarta students, especially in the petroleum engineering department.

Do you know the uses and SOPs for using the following tools: (1) Electronic Density Balance (2) Brookfield Viscometer (3) Spinning Drop IFT (4) Gas Chromatography Trace GC 1310 (5) Core Flooding (6) Oven Memmert UNB 400?

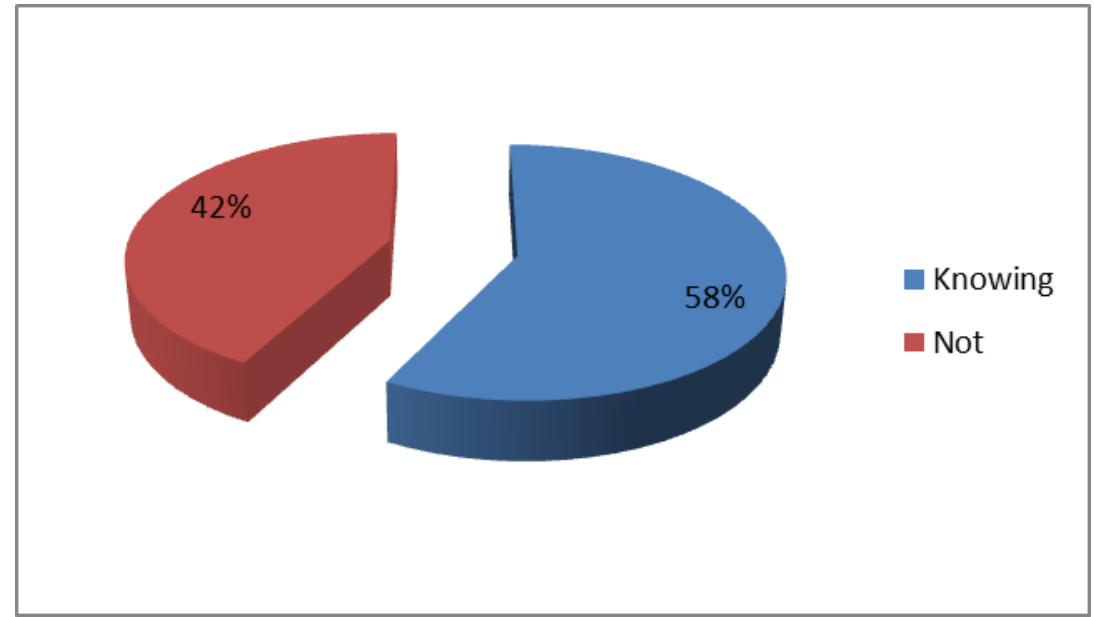

Figure 6. Student's knowledge about the uses and SOPs for using the tools

The fourth question was about students' knowledge of SOPs for using tools such as Electronic Density Balance, Brookfield Viscometer, Spinning Drop IFT, Gas Chromatography Trace GC 1310, Core flooding, and Oven Memmert UNB 400 only 58\% (30 out of 52) knew its use while $42 \%$ (22 of 52) do not know the use of the tools in the EOR Laboratory. This is very likely to happen because, like previous surveys, knowledge about the EOR Laboratory is still very minimal among students, even for students who have been studying for almost 4 years.

Are there any other equipment and materials (other than those mentioned above) that students need to conduct research in the EOR lab?

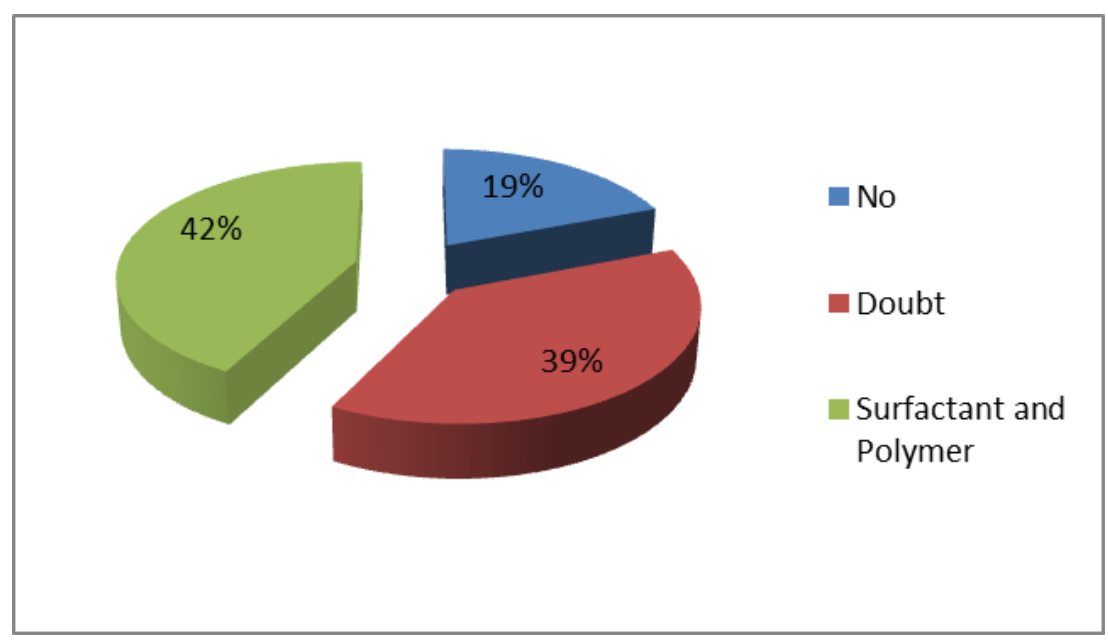

Figure 7. Equipment and other materials that students need to conduct research in the 
The fifth question regarding student needs related to equipment other than those mentioned in question $4,19 \%$ of respondents said no, $39 \%$ said they were unsure and $42 \%$ said they needed surfactants and polymers. It can be conclude that it is necessary to update the governance of the EOR Laboratory and also socialize because $39 \%$ are hesitant as a result of ignorance of the EOR Laboratory.

What are the obstacles faced by students when using the EOR Laboratory?

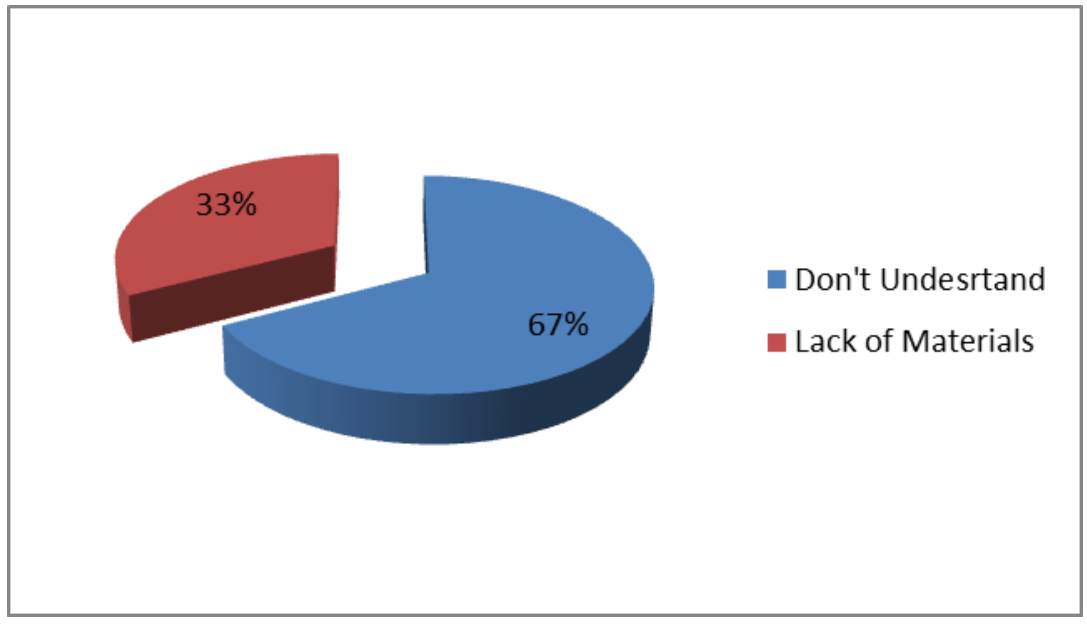

Figure 8. Obstacles faced by students when using the EOR Laboratory

The sixth question is about whether there are obstacles when using the EOR Laboratory, $67 \%$ of respondents said they did not know and 33\% said they lacked materials. Most of the students had never tried using the EOR laboratory so they could not explain the obstacles when using the Laboratory.

Should the application for the use of laboratory facilities be made in digital form?

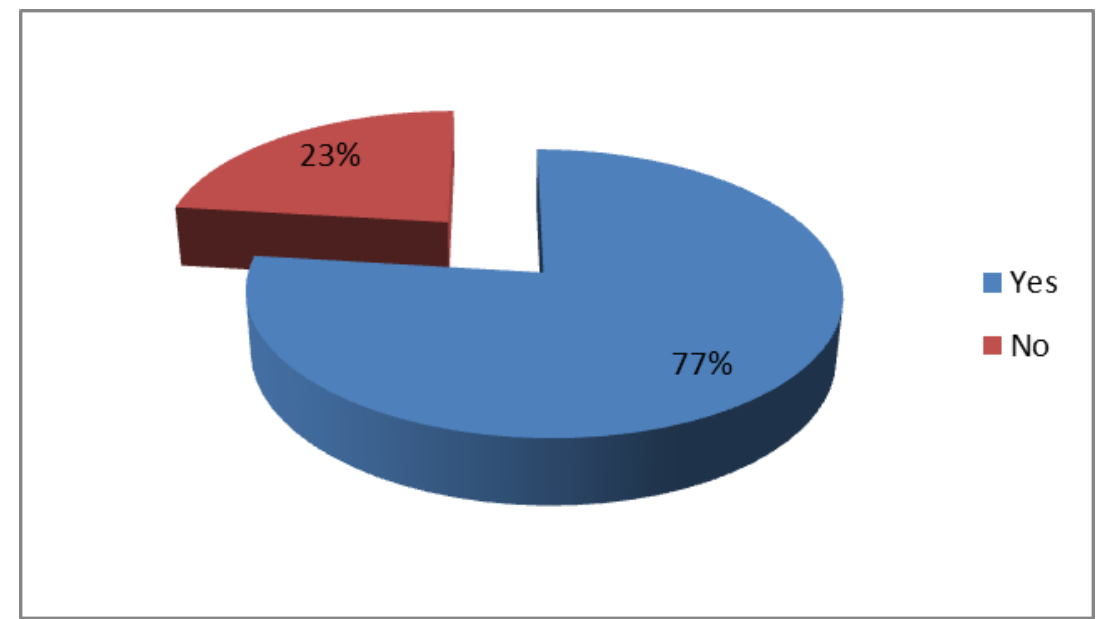

Figure 9. Scale of responses for requests for use of laboratory facilities are made in digital form 
The seventh question is about the need for laboratory applications use to be made in digital form. The respondents about 40 from 52 chose yes (77\%) and 12 from 52 (23\%) chose no. So that students require applications to be made digitally.

Should a digital invoice tracking system be implemented in the use of the laboratory?

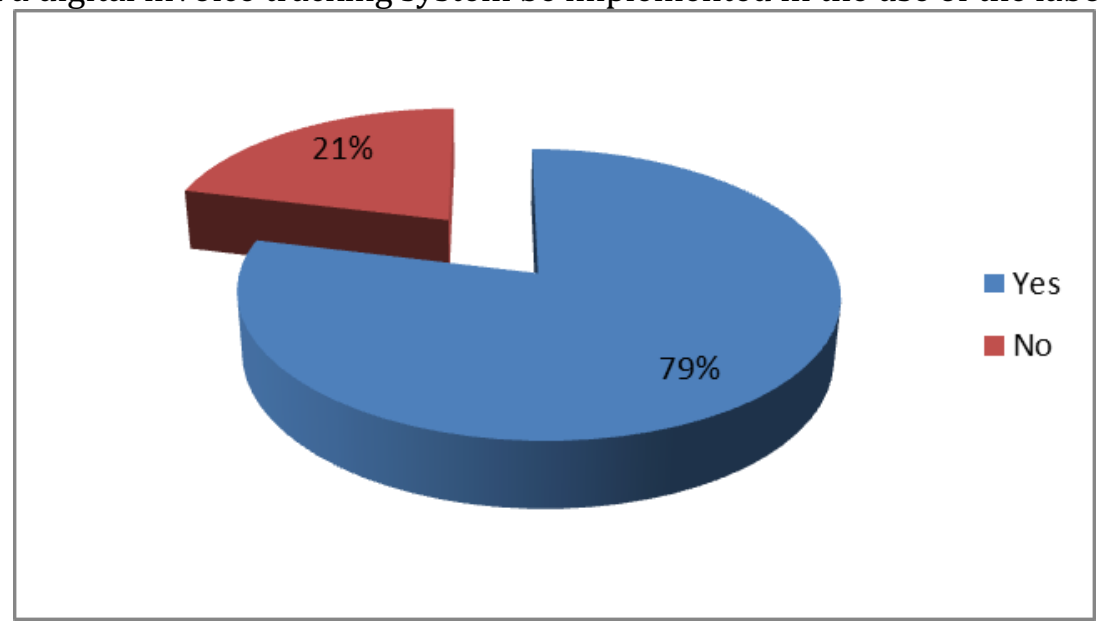

Figure 10. Scale of responses about digital invoice tracing system

The eight question is about the need to apply a digital invoice tracking system in the use of laboratories, the invoice creation process is updated on every completed work. The survey showed 41 from 52 of respondents chose yes and 11 from 52 chose no. Students agreed if there was digitally invoice tracking system.

The ninth question is about comfortable laboratory standards according to the respondents. According to respondents, a good laboratory is a laboratory where all the tools can function properly, are clean and well organized, and have SOPs for the use of tools.

Should there be a more intense socialization regarding the EOR lab to both internal (lecturers, undergraduate and postgraduate students) and external (companies)?

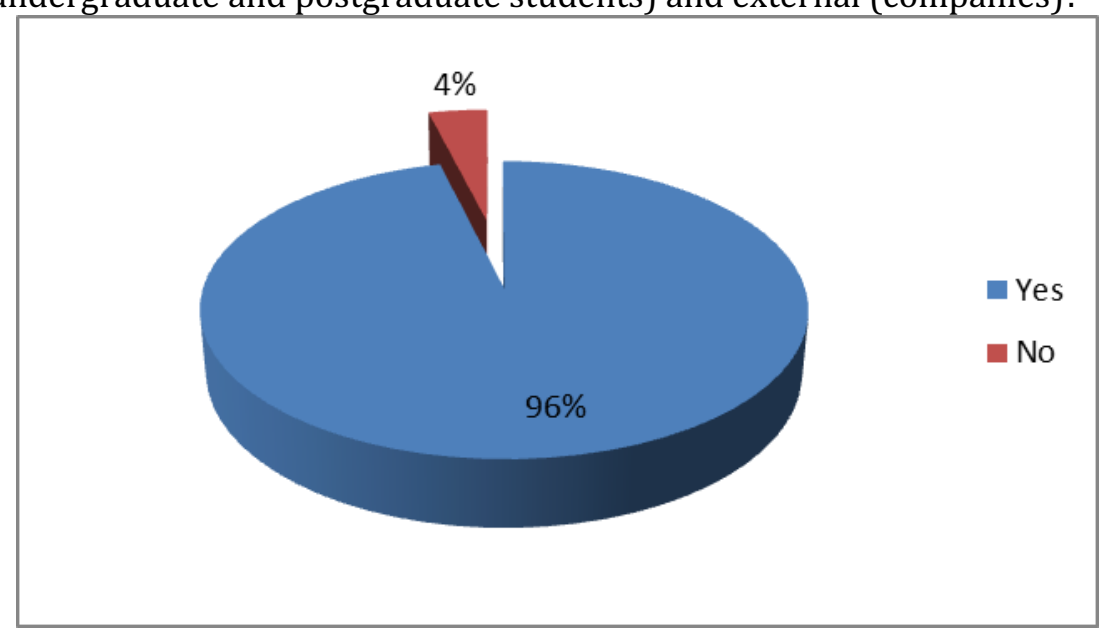

Figure 11. Scale of Response There is a need for a more intense socialization regarding the EOR lab to both internal and external parties

The tenth question is about the need for more intense socialization to internal (lecturers, undergraduate and postgraduate students) and external (companies). The respondents amount 50 
from $52(96 \%)$ chose yes and 2 from 52 (4\%) chose no. Answers of respondents conclude that more intense socialization is needed for internal and external.

The last question is about the most effective form of socialization or promotion regarding the EOR laboratory for internal and external circles. Respondents' answers varied, such as through webinars, direct introductions, using social media, through videos containing laboratory introductions, lecturer submissions, and posters.

From the survey answers by 52 respondents with 11 questions regarding the EOR Laboratory, it is known that the EOR Laboratory requires several things to create an effective and efficient laboratory. The first is socialization, from the many survey answers that were presented, most of the respondents did not know the location of the EOR laboratory, the SOP for the tools in the EOR Laboratory, so socialization was needed, especially among students. It was also seen that many of the students were interested in researching at the EOR Laboratory but did not know about the existence of this EOR Laboratory at UPN "Veteran" Yogyakarta. Respondents suggested various ways to conduct socialization such as holding webinars, introductions by lecturers, using social media, and using posters.

Second, the layout of the EOR Laboratory space management. Apart from promoting, it is also necessary to improve governance because in the survey answers there were respondents who said that the EOR Laboratory lacked practical materials such as surfactants and polymers. Several respondents also agreed that a comfortable laboratory standard is a laboratory where all the equipment can function properly, is clean, tidy, and comfortable to use. So it needs to be improved to meet the standards of the University Research Laboratory.

Third, effective and efficient laboratory management. Respondents on average chose a scale of 3-5 from a scale of 1 to 5 in terms of the need for applications for the use of laboratory facilities in digital form. It stated that the respondents agreed to hold the application digitally. In addition, on a scale of 1 to 5 , the respondents chose a scale of 3-5 in terms of the application of a digital invoice tracking system in laboratory use. So, universities need to consider digital services to be effective and efficient.

\section{CONCLUSION AND FURTHER RESEARCH}

Based on the survey results, it can be said that students have an interest in research at the EOR Laboratory. However, there are several obstacles faced by students related to the lack of knowledge about the location of the laboratory, the use and SOP of the tools in the EOR Laboratory, and minimal laboratory materials. As a follow-up to this research, the Department of Petroleum Engineering can increase the introduction of the EOR Laboratory to students either by socializing through webinars, coordinating with lecturers, or making introduction videos. governance by meeting the requirements of complete tools and materials, comfortable, neat, and clean space management. In addition, the management of the EOR laboratory is also effective and efficient with digital management.

\section{ACKNOWLEDGEMENTS}

The authors would like to thank LPPM UPN "Veteran" Yogyakarta which for funding this research.

\section{REFERENCES}

Ahmad Fauzi A. Wahab. (2005). Pengurusan Sumber Fizikal IPT: Pengurusan ruang.Jurnal Teknologi 43(E). Universiti Teknologi Malaysia.

Borg, WR, Gall, MD, \& Gall, JP. (1983). Educational Researh. Boston: Pearson Education Inc. Elly Yuliawati (2004). Kurikulum dan Pembelajaran, Filosofi Teori dan Aplikasi. Bandung: Pakar Raya. Emda, Anna.2017. Laboratorium Sebagai Sarana Pembelajaran Kimia Dalam Meningkatkan 
Fayol, Henri (1916): General and Industrial Management (English edition 1949). London: Sir Isaac Pitman \& Sons Ltd (first published in French in "bulletin de Ia sociéte de'industrieminérale"

Manabu Sato (2007). Tantangan yang Harus Dihadapi Sekolah. Bahan Rujukan UntukLesson Nasional.

Novianti, Nur Raina.2011. Kontribusi Pengelolaan Laboratorium Dan Motivasi Belajar Siswa Terhada Efektivitas Proses Pembelajaran. Edisi Khusus No. 1, Agustus2011, Hal.158-166, ISSN 1412$565 \mathrm{X}$

Pengetahuan Dan Ketrampilan Kerja Ilmia. Lantanida Journal, Vol. 5 No. 1, 2017, Hal.83-93.

Rahmiyati,Sri.2008. The Effectiveness Of Laboratory Use In Madrasah Aliyah In Yogyakarta. Jurnal Penelitian dan Evaluasi Pendidikan, Nomor 1, Tahun XI, 2008, Hal.88-100.

Rakhman, Aditya, Setabudi, Agus, \& Muzdzakir, 2015.Ahmad. Perancangan Pembelajaran Literasi Sains Berbasis Inkuiri Pada Kegiatan Laboratorium.Jurnal Penelitian dan Pembelajaran IPA,Vol 1, No , November 2015, Hal. 143-152 e-ISSN 2477-2038.

Study.

Undang-Undang Negara Republik Indonesia Nomor 12 Tahun 2012 tentang Pendidikan Tinggi Undang-Undang Negara Republik Indonesia Nomor 20 Tahun 2003 tentang Sistem Pendidikan 